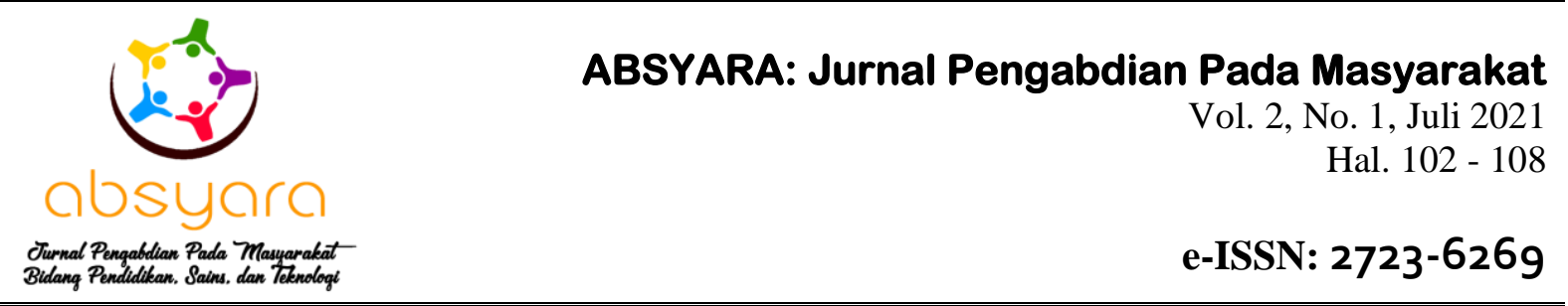

\title{
Pelatihan Pembuatan Masker Kain dalam Upaya Mencegah Penularan Covid 19 di Surakarta
}

\begin{abstract}
Eko Meiningsih Susilowati
susilowatieko74@gmail.com

Program Studi Akuntansi, STIE-AUB Surakarta

Received: 31 Mei 2021

Accepted: 13 Juli $2021 \quad$ Online Published: 31 Juli 2021

DOI: 10.29408/ab.v2i1.3583

URL: http://dx.doi.org/10.29408/ab.v2i1.3583

Abstrak: Sejak tahun 2020, Indonesia telah dilanda pandemi Covid 19 sehingga masyarakat harus menerapkan protokol kesehatan. Pemerintah telah membuat aturan agar masyarakat wajib menggunakan masker. Peraturan ini sempat membuat harga masker menjadi sangat tinggi. Hal ini mengakibatkan masker menjadi sangat langka dan mahal. Berdasarkan situasi tersebut kegiatan ini bertujuan untuk melatih masyarakat Kampung Tegalharjo, Jebres, Surakarta dalam membuat masker kain dan dapat menjual masker tersebut. Pelaksanaan kegiatan pada tanggal 9 Agustus 2020 di Kampung Tegalharjo Kecamatan Jebres Kota Surakarta. Metode yang digunakan adalah dengan cara ceramah, praktek dan diskusi. Sebagai mitra dalam kegiatan ini hanya satu yaitu kelompok ibu rumah tangga di Kampung Tegalharjo yang berjumlah 12 orang. Hasil yang didapatkan sebanyak 80\% mitra di kampung tersebut dapat membuat masker kesehatan yang terbuat dari kain dengan baik dan dapat menjualnya atau memasarkannya untuk memperoleh laba dan bisa menambah pemghasilan. Sehingga dari hasil penjualan tersebut dapat membantu meningkatkan kesejahteraan hidup. Untuk selanjutnya agar dapat memasarkan hasil produknya secara lebih luas lagi dan lebih banyak lagi dilakukan penjualan secara online.
\end{abstract}

Kata Kunci: Covid-19; Masker Kain; Pembuatan Masker Kain

\begin{abstract}
Since 2020, Indonesia has been hit by the Covid-19 pandemic, so people must implement health protocols. The government has made rules so that people are required to wear masks. This regulation had made the mask are rare, and the price is very high. Based on this situation, this activity aims to train the people of Kampung Tegalharjo, Jebres, Surakarta to make masks and sell these masks. On August 9, 2020, the activity was carried out in Tegalharjo Village, Jebres District, Surakarta City. The method used is by way of lectures, practice, and discussion. As a partner in this activity, only one group of housewives in Tegalharjo Village totaled 12 people. The results obtained are that as many as $80 \%$ of partners in the village can make health masks made of cloth well and can sell them or market them for profit and can increase income. So that the sales proceeds can help improve the welfare of life. Henceforth, in order to be able to market their products more widely and sell more online.
\end{abstract}

Keyword: Covid-19; Mask; Mask Making Training 


\section{PENDAHULUAN}

Virus Corona dapat menyebabkan penyakit pada manusia dan binatang. Saat ini ada jenis baru yaitu Covid 19. Karena itu harus selalu menerapkan protokol kesehatan yang dicanangkan pemerinatah melalui 3M: 1) Mencuci tangan; 2) Memakai masker; 3) Menjaga jarak (Sundari, dkk, 2020). Penularan Covid 19 yang paling rentan adalah pembeli dan pedagang di pasar. Di pasar tradisional pedagang dan pembeli minim informasi mengenai pencegahan Covid 19. Para pedagang dan pembeli belum menyadari betul betapa besarnya manfaat penggunaan masker di pasar tradisional (Martina, dkk., 2020). Masyarakat merasa takut akan tertular virus yang mematikan tersebut. Pemerintah mewajibkan kepada seluruh masyarakat untuk mengenakan masker. Hal ini membuat permintaan masker melonjak di pasaran, sehingga masker di pasaran untuk tenaga kesehatan menjadi langka khususnya di apotik. Masyarakat membutuhkan banyak masker untuk memenuhi kebutuhan tersebut. Bagi masyarakat hal ini bisa menjadi peluang untuk memproduksi masker yang terbuat dari kain. Bagi masyarakat yang bisa menjahit dan yang tidak bisa menjahitpun bisa memproduksi masker tesebut. Masker ada beberapa macam jenisnya. Misalnya masker bedah dan respirator N95. Sedangkan bagi masyarakat umum untuk menjaga kesehatan dan agar tidak tertular virus Corona dibutuhkan masker baik yang terbuat dari kain maupun masker yang digunakan untuk tenaga kesehatan.

Bagi mereka yang mempunyai kemampuan menjahit atau yang baru belajar menjahit bisa membuat masker sendiri. Setelah mereka membuat masker-masker tersebut untuk diri sendiri, mereka dapat membuat dalam jumlah yang banyak. Tujuan membuat dalam jumlah yang banyak adalah untuk dijual. Dengan menjual masker ini diharapkan masyarakat dapat memperoleh keuntungan. Keuntungan ini dapat menambah penghasilan di masa pandemi. Masker yang terbuat dari kain tidak dapat memberikan keamanan yang maksimal, tetapi masker yang terbuat dari kain ini bisa membantu mengurangi penularan virus pada saat kondisi seperti ini. Untuk menjual dan memasarkan produk memerlukan pemahaman yang baik mengenai fungsi pemasaran yaitu pengenalan produk, riset, distribusi dan layanan purna jual (Priharto, 2019). Produk sendiri adalah segala sesuatu yang dapat ditawarkan ke pasar untuk dipakai atau dikonsumsi guna memenuhi kebutuhan dan keinginan konsumen (Prawiro, 2019). Sedangkan produksi adalah proses yang mengubah bahan baku menjadi barang atau produk jadi atau menambah nilai suatu produk yang berupa barang dan jasa untuk memenuhi kebutuhan masyarakat. Tujuan dalam kegiatan produksi yang dilakukan oleh para produsen adalah untuk memenuhi kebutuhan masyarakat dan untuk memperoleh keuntungan (Prawiro, 2018).

\section{METODE PELAKSANAAN}

\section{Waktu dan Lokasi}

Kegiatan ini berlangsung mulai bulan Maret sampai dengan bulan Agustus tahun 2020 yang berarti selama kurang lebih enam bulan lamanya. Tempat kegiatan dilakukan di salah satu rumah warga di Kelurahan Tegalharjo Kecamatan Jebres Surakarta. Metode yang digunakan dalam kegiatan ini adalah ceramah, praktek dan diskusi. Mitranya adalah warga di Kampung Tegalharjo yang berjumlah sebanyak 12 orang. Mitra mempunyai tugas yaitu ikut membantu dalam menyiapkan peralatan dan perlengkapan yang dibutuhkan yang akan digunakan untuk 
melakukan praktek dalam pembuatan masker yang terbuat dari kain. Mitra juga ikut membantu dalam pemilihan tempat yang akan digunakan dalam melakukan praktek membuat masker tersebut.

\section{Prosedur pelaksanaan}

1. Persiapan

Tahap ini dilakukan dengan melakukan sosialisasi kepada mitra. Untuk selanjutnya yaitu mengurus perijinan dan mengurus bermacam-macam perlengkapan yang dibutuhan untuk pelaksanaan kegiatan.

2. Pelaksanaan

a. Memberikan pemahaman kepada mitra mengenai pentingnya protokol kesehatan dan bahayanya virus Corona. Dalam hal ini diharapkan agar mitra dapat benar-benar memahami dan menyadari akan pentingnya menjaga kesehatan.

b. Memberikan pelatihan tentang bagaimana cara membuat masker yang terbuat dari kain yang dapat digunakan untuk mencegah penularan virus Corona dan melakukan pendampingan secara berkelanjutan mengenai penjualan atau pemasaran masker dari kain tersebut.

3. Evaluasi

Produk masker dibuat dari kain yang lebih baik dengan tampilan yang lebih bagus dan menarik. Dan berapa jumlah masker yang dihasilkan tersebut berhasil terjual.

\section{HASIL DAN PEMBAHASAN}

\section{HASIL}

Hasil dari kegiatan pengabdian kepada masyarakat ini adalah:

a. Pelaksanaan

Hasil dari pelaksanaan kegiatan ini adalah mitra dapat mengikuti semua rangkaian cara dalam pembuatan masker dari kain dan mitra dapat membuat masker yang terbuat dari kain tersebut dengan baik dan benar.

b. Pendampingan

Hasil dari pendampingan ini mitra dapat membuat masker yang terbuat dari kain dengan mutu yang lebih baik dan menarik. Mitra juga dapat menjual masker-masker tersebut dengan cara melalui penjualan online.

c. Evaluasi

Hasil dari evaluasi ini adalah mitra dapat membuat masker dengan model yang lebih variatif dengan tidak mengurangi fungsinya dan memberikan harga yang lebih terjangkau karena persaingan yang semakin ketat.

Kegiatan ini adalah membuat masker kesehatan dari bahan kain dan cara memasarkannya untuk meningkatkan penghasilan. Tidak lupa harus selalu menjaga kesehatan melalui pencegahan. Termasuk memberikan edukasi kepada kader posyandu sebagai mediator informasi mengenai kesehatan di masyarakat merupakan langkah awal dalam penyelesaian masalah (Atmadja, dkk., 2020). Masyarakat akan paham cara pencegahan penularan Covid 19 ini dan masyarakat dapat mengaplikasikan pencegahan penularan virus ini dengan mencuci 
tangan dan memakai masker (Kartikasari \& Kurniawati, 2020). Kegiatan ini dilaksanakan pada tanggal 9 Agustus 2020. Hasil dari pelatihan ini adalah mitra dapat membuat masker dengan baik dan dapat memasarkannya atau menjualnya. Hal ini bisa dilihat sebanyak $80 \%$ peserta bisa membuat masker tersebut dengan baik dan dapat memperoleh keuntungan dengan membuat masker untuk diri sendiri dan menjualnya untuk mendapatkan penghasilan.

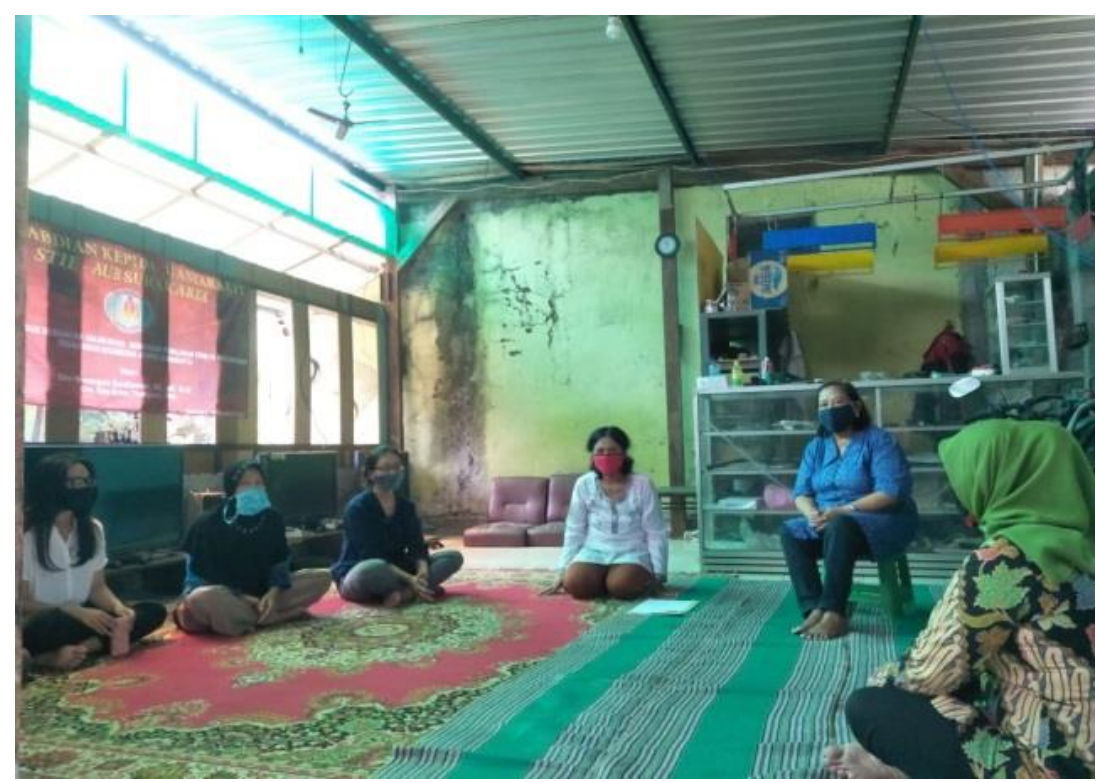

Gambar 1. Pembukaan Acara Pelatihan

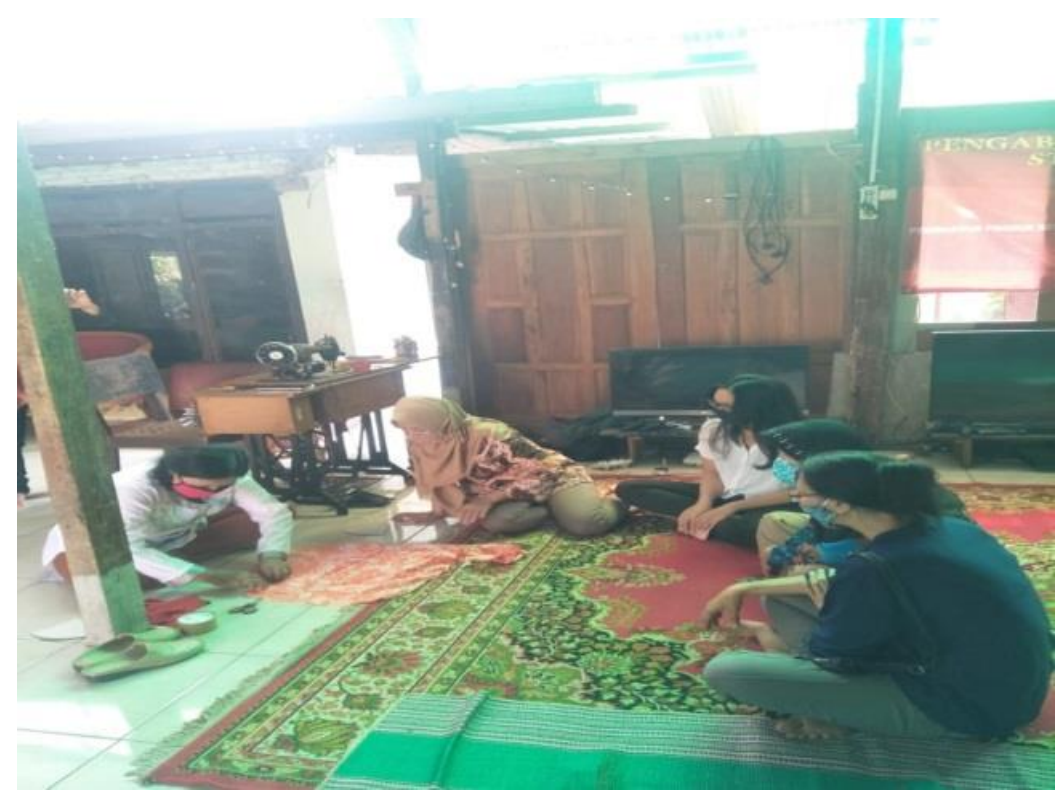

Gambar 2. Praktek Pembuatan Masker Dari Kain 


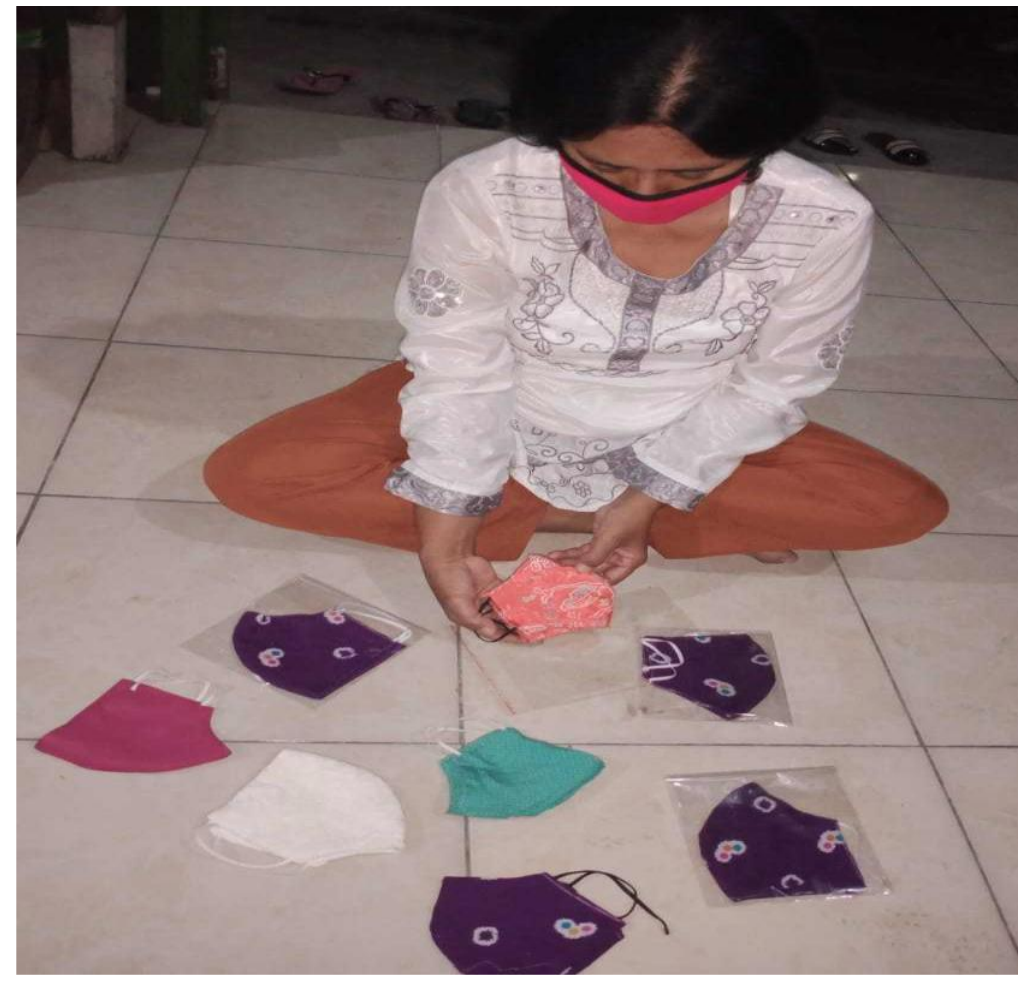

Gambar 3. Pengemasan Hasil Produk

\section{PEMBAHASAN}

Lingkungan masyarakat yang sehat akan membuat warganya bahagia dan nyaman dalam menjalankan kehidupan sehari-hari. Tetapi kenyamanan masyarakat terusik dengan adanya pandemi virus Corona. Pada situasi seperti ini pemerintah mengeluarkan peraturan yang harus ditaati untuk pencegahan penularan virus Covid-19 semakin banyak. Peraturan tersebut adalah berupa social distancing, lock down, karantina, isolasi mandiri, social containment, PSBB dan melakukan ibadah tetap di rumah saja (Risfianty \& Indrawati, 2020). Pembagian poster, masker, sabun, dan juga vitamin juga dapat meningkatkan pengetahuan dan dapat membantu masyarakat dalam menjaga kesehatan dan bisa membantu pemerintah untuk menanggulangi penularan penyakit ini (Purwanti, dkk., 2020). Saat ini telah terjadi pandemi, yaitu adanya penyebaran virus di hampir seluruh dunia. Virus tersebut namanya adalah virus Corona atau Covid-19. Covid-19 adalah virus jenis baru yang belum pernah diidentifikasi sebelumnya pada manusia. Tanda dan gejala umum infeksi virus Covid-19 antara lain adanya gejala gangguan pernapasan akut seperti demam, batuk dan sesak napas (Wulandari, 2020). Pemerintah sudah melakukan banyak cara agar penyebaran virus ini segera berhenti atau paling tidak berkurang. Pemerintah melakukan cara yaitu mengharuskan masyarakat untuk memakai masker, mencuci tangan, dan menghindari kerumunan. Tetapi pemerintah sulit untuk mengendalikannya karena virus ini penyebarannya begitu cepat dan masyarakat banyak yang tidak patuh, sehingga semakin hari penyebaran virus tersebut semakin luas dan banyak menelan korban jiwa. Selain itu pemerintah juga menghimbau masyarakat untuk sering menggunakan hand sanitizer atau menggunakan anti septik di lingkungan sekitar.

Hasil dari pelatihan ini adalah $80 \%$ mitra dapat membuat masker dengan baik serta dilakukan dengan benar, juga para peserta dapat memasarkannya atau menjualnya dengan efektif, dan peserta juga dapat mengetahui apakah dalam pembuatan dan pemasaran tersebut 
mereka dapat meningkatkan atau menambah penghasilan. Dalam pembuatan masker kain agar dapat bertahan dan berkembang dengan baik bisa dilakukan cara dengan melakukan inovasi, menjaga kualitas dan meningkatkan penjualan dengan mengirim produk pada saat itu juga (Wahyuningsih, dkk., 2021). Melakukan inovasi dengan membuat masker dalam bermacam model dan bentuk. Meskipun bermacam-macam model dan bentuknya tetapi jangan melupakan fungsinya. Menjaga kualitas dengan membuat masker dari bahan yang nyaman dan aman sesuai dengan fungsinya. Meningkatkan penjualan dengan cara megirim segera masker apabila sudah ada pemesan atau sudah ada pembeli. Dalam mengembangkan kemampuan menjahit kepada mitra, sudah tercapai tujuan yang diharapkan. Hal ini bisa dilihat dari berhasilnya mencapai target pembuatan masker yang dapat diberikan ke masyarakat (Armiani, dkk., 2020). Jangan sampai terjadi penularan penyakit yang lebih banyak lagi jumlahnya dan disamping itu mereka bisa mendapatkan keuntungan dari kegiatan ini. Tim telah mendampingi pembuatan masker dan pemasaran dalam meningkatkan penghasilan. Penghasilan yang diperoleh harapannya agar dapat digunakan untuk meningkatkan kualitas hidup dengan cara meningkatkan kebutuhan akan gizi yang lebih baik lagi, sehingga terhindar dari penyakit yang menular.

\section{SIMPULAN}

Hasil kegiatan ini adalah hampir semua peserta mampu membuat masker dengan baik termasuk dalam hal pengemasannya juga sudah baik dan sebagian peserta sudah mampu menjualnya meskipun sementara ini hanya dijual di sekitar tempat tinggal mereka. Dengan sudah menjual masker-masker tersebut peserta mendapatkan tambahan penghasilan yang bisa digunakan untuk membantu mencukupi kebutuhan hidup sehari-hari.

\section{PERNYATAAN PENULIS}

Artikel ini merupakan hasil karya sendiri yang belum pernah dipublikasikan baik secara keseluruhan maupun sebahagian, dalam bentuk jurnal, working paper atau bentuk lain yang dipublikasikan secara umum. Karya ilmiah ini sepenuhnya merupakan karya intelektual dan seluruh sumber yang menjadi rujukan dalam karya ilmiah ini telah sebutkan sesuai kaidah akademik yang berlaku umum, termasuk para pihak yang telah memberikan kontribusi pemikiran pada isi, kecuali yang menyangkut ekspresi kalimat dan disain penulisan.

\section{DAFTAR PUSTAKA}

Armiani, S., Fajri, S. R., Sukri, A., \& Pidiawati, B. Y. (2020). Pelatihan pembuatan masker sebagai upaya antisipasi penyebaran Covid-19 di Desa Anyar Kabupaten Lombok Utara. Jurnal Pengabdian UNDIKMA, 1(1), 22-27.

Atmadja, T. F. A., Sulistyaningsih, D., \& Mahmudah, I. R. (2020). Edukasi gizi seimbang sebagai perisai penularan Covid-19 pada Kader Posyandu Bina Sejahtera dan Posyandu Tulip. Abdi Dosen: Jurnal Pengabdian Pada Masyarakat, 4(4), 397-404.

Kartikasari, D., \& Kurniawati, T. (2020). Kesiagaan Covid 19 dengan memberikan penyuluhan tentang cuci tangan dan pembagian masker kepada masyarakat di Pasar Batang Kabupaten Batang. Jurnal Pengabdian Masyarakat IPTEKS, 6(1), 63-66. 
Susilowati, E. M. (2021). Pelatihan pembuatan masker kain dalam upaya mencegah penularan Covid 19 di Surakarta. ABSYARA: Jurnal Pengabdian Pada Masyarakat, 2(1), 102-108. doi:10.29408/ab.v2i1.3583

Martina, S. E., Amila, A., \& Sembiring, E. (2020). Peduli Covid-19, berbagi masker pada pedagang pasar tradisional. AMALIAH: JURNAL PENGABDIAN KEPADA MASYARAKAT, 4(2), 176-185.

Priharto, S. (2019, Agustus 2). Pengertian pemasaran, fungsi, dan jenis pemasaran dalam bisnis. Retrieved from CPSSOFT:

https://cpssoft.com/blog/bisnis/pengertian-pemasaran-fungsi-dan-jenis-pemasarandalam-bisnis/

Prawiro, M. (2018, Agustus 3). Pengertian produksi: fungsi, tujuan, dan jenis-jenis produksi. Retrieved from Maxmanroe.com: https://www.maxmanroe.com/vid/bisnis/pengertian-produksi.html

Prawiro, M. (2019, November 27). Pengertian Produk: Definisi, Jenis, Tingkatan, dan Contoh Produk. Retrieved from Maxmanroe.com: https://www.maxmanroe.com/vid/bisnis/pengertian-produk.html

Purwanti, I. S., Devhy, N. L. P., Prihatiningsih, D., Bintari, N. W. D., \& Widana, A. G. O. W. O. (2020). Implementasi pengabdian masyarakat berbasis kesehatan dalam upaya pencegahan penyakit Covid 19 di Desa Bedulu Gianyar Bali. Jurnal Pengabdian UNDIKMA, 1(2), 106-110.

Risfianty, D. K., \& Indrawati, I. (2020). Pemberdayaan kesehatan masyarakat melalui pengadaan fasilitas cuci tangan pada masa pandemi Covid-19 di Masjid dan Mushala Dusun Montong Are Tengah. Jurnal Pengabdian UNDIKMA, 1(2), 94-99.

Sundari, S., Taher, D. M., Nurhasanah, N., Mas' ud, A., \& Hasan, S. (2020). Pendampingan pembuatan hand sanitizer berbasis kearifan lokal (ekstrak tangkai bunga cengkeh). ABSYARA: Jurnal Pengabdian Pada Masyarakat, 1(2), 49-55.

Wahyuningsih, R., Rahayu, E. P., Maulana, D., \& Pratiwi, R. (2021). Pemberdayaan masyarakat jombang berbasis kewirausahaan melalui pendampingan pembuatan masker kain di masa Pandemi Covid-19. Jurnal Pengabdian UNDIKMA, 2(1), 50-58.

Wulandari, A., Rahman, F., Pujianti, N., Sari, A. R., Laily, N., Anggraini, L., ... \& Prasetio, D. B. (2020). Hubungan karakteristik individu dengan pengetahuan tentang pencegahan Coronavirus Disease 2019 pada masyarakat di Kalimantan Selatan. Jurnal Kesehatan Masyarakat Indonesia, 15(1), 42-46. 